\title{
Hubungan Pengetahuan dan Sikap Mahasiswi dengan Tindakan Perawatan Organ Reproduksi di Akademi Kebidanan Internasional Pekanbaru
}

\section{The Relation between Knowledge and Attitude of Coed With Treatment Action of Reproductive Organ in Academy Midwifery Internasional of Pekanbaru}

\author{
Sentya Putri* Yeyen Gumayesty* Deswinda**
}

\author{
*Prodi Ilmu Kesehatan Masyarakat STIKes Hang Tuah Pekanbaru, **Prodi Ilmu Keperawatan \\ Payung Negeri Pekanbaru
}

\begin{abstract}
ABSTRAK
Perawatan organ reproduksi wanita diperlukan untuk menghindari beberapa permasalahan organ reproduksi seperti iritasi, infeksi, alergi dan karsinoma. Survei awal yang dilakukan peneliti dari pada 20 orang mahasiswi menunjukkan pengetahuan mereka cukup baik, tetapi masih ada 25\% mahasiswi yang tidak melakukan perawatan organ reproduksi. Tujuan penelitian ini adalah untuk mengetahui hubungan pengetahuan dan sikap mahasiswi dengan tindakan perawatan organ reproduksi di Akademi Kebidanan Internasional Pekanbaru. Jenis penelitian kuantitatif analitik dengan desain cross sectional. Populasi adalah seluruh mahasiswi tingkat I di Akademi Kebidanan Internasional Pekanbaru. Seluruh populasi dijadikan sebagai sampel dengan besar sampel adalah 100 orang mahasiswi. Pengumpulan data dilakukan dengan menyebarkan kuesioner. Hasil penelitian menunjukkan bahwa sebagian besar mahasiswi mempunyai pengetahuan baik sebanyak 86 orang $(86 \%)$ dan mempunyai sikap positif sebanyak 59 orang $(59 \%)$, serta sebagian responden melakukan tindakan perawatan organ reproduksi sebanyak 52 orang (52\%). Hasil uji chi-square pengetahuan dan sikap dengan tindakan perawatan organ reproduksi dengan $p$ value yang sama yaitu $p=0,006$. Disimpulkan bahwa ada hubungan yang signifikan antara pengetahuan dengan tindakan perawatan organ reproduksi dengan OR 8,33 (95\% CI : 1,75-39,54) dan ada hubungan signifikan antara sikap dengan tindakan perawatan organ reproduksi dengan OR $=3,49(95 \%$ CI : 1,51-8,06). Saran penelitian ini diharapkan bagi peneliti selanjutnya untuk dapat melakukan penelitian pada remaja awal dengan jenis penelitian dan variabel yang berbeda.
\end{abstract}

Kata Kunci: Pengetahuan, Sikap, Tindakan Perawatan Organ reproduksi

\section{ABSTRACT}

Treatment of the female reproductive organ is necessary to avoid some problems such as irritation of the reproductive organs, infections, allergies and carcinoma. Early survey conducted to 20 peoples of coed shows their knowledge is quite good, but there was still 25\% of coed who did not give any treatment to their reproductive organ properly. The aim of this research is to know the relation between knowledge and attitude with action treatment of reproductive organ in International Academy Midwifery of Pekanbaru. The Types of research was quantitative analytic to cross sectional design. The population is the entire student at the International Midwifery Academy I in Pekanbaru. The entire sample population used as the sample size is 100 female students. The data was collected by distributing questionnaires. The results showed that most of the student have a good knowledge of as many as 86 people (86\%) and having a positive attitude as many as 59 people (59\%), and most respondents reproductive care measures by 52 people (52\%). The result of chi-square test indicates that the attitude and knowledge with treatment action to reproductive organ has the same value that is $p=0,006$. It is concluded that there is a significan relation between knowledge and treatment action of reproductive organ with OR 8,33 (95\% CI:1,75-39,54) and also there is a significan relation between attitude and and treatment action of reproductive organ with OR $=3,49(95 \% \mathrm{CI}$ : 1,51-8,06). This research suggests a further research on adolescent with a different type of research and variable

Keywords: Knowledge, Attitude, Threatment Action to Reproductive Organ

\section{PENDAHULUAN}

Remaja didefinisikan sebagai masa peralihan dari masa kanak-kanak ke masa dewasa, dimana terjadi pacu tumbuh, timbul ciri-ciri seks sekunder, tercapainya fertilitas dan terjadi perubahan-perubahan psikologik serta kognitif. Untuk tercapainya potensi biologik seorang remaja merupakan hasil interaksi antara faktor genetik dan lingkungan biofisiko psikososial (Soetjiningsih, 2004). Kesehatan reproduksi adalah suatu keadaan sejahtera fisik, mental dan sosial secara utuh, tidak semata-mata bebas dari penyakit atau kecacatan dalam semua hal yang berkaitan dengan 
sistem reproduksi, serta fungsi dan prosesnya. Kesehatan reproduksi remaja adalah suatu kondisi sehat yang menyangkut sistem, fungsi dan proses reproduksi yang dimiliki oleh remaja. Remaja perlu mengetahui kesehatan reproduksi agar memiliki informasi yang benar mengenai proses reproduksi serta berbagai faktor yang ada disekitarnya. Oleh karena itu, dengan adanya informasi yang benar diharapkan remaja memiliki pengetahuan yang baik serta sikap dan tingkah laku yang bertanggung jawab mengenai proses reproduksi (Maulana, 2008).

Organ reproduksi manusia adalah bagian tubuh yang paling sensitif, sehingga terletak di bagian tengah tubuh yang paling tersembunyi. Organ reproduksi bagian luar sering disebut sebagai organ kelamin. Organ kelamin merupakan organ intim yang sangat sensitif karena mempunyai banyak ujung saraf perasa (sensoris). Ujung saraf perasa membuat kulit lebih peka terhadap rangsangan (Dwikarya, 2004).

Beberapa permasalahan pada organ intim berupa iritasi, infeksi dan alergi. Kulit bagian luar organ intim tertutup oleh rambut yang disebut pubis. Pubis selain merupakan mahkota kedewasaan juga berfungsi sebagai pelindung kulit organ intim yang cukup sensitif. Kulit bagian dalam organ intim lebih tipis sehingga rentan terhadap trauma fisik dan kimia. Trauma fisik ini misalnya akibat terkena air panas, luka garukan dan gesekan benda asing. Trauma kimia bisa disebabkan oleh luka akibat pemakaian sabun pembersih (Dwikarya, 2004).

Masalah iritasi juga dapat terjadi karena seseorang terobsesi ingin selalu bersih, sehingga terlalu banyak menggunakan sarana pembersih organ intim, seperti mencuci dengan air panas, membilas dengan sabun terlalu banyak, dan menggunakan kompres larutan obat yang terlalu pekat. Dimana dampaknya akan membuat organ reproduksi menjadi iritasi atau bahkan sampai ke gejala selanjutnya seperti infeksi. Masalah alergi pada kulit organ intim dapat disebabkan oleh alergi kontak dan alergi obat makan. Beberapa yang ditemukan mengalami alergi kontak terhadap pemakaian pembalut wanita baik yang tebal maupun yang tipis (Dwikarya, 2004).

Hasil survei di Indonesia, menunjukan bahwa penduduk remaja putri yang berumur 10-24 tahun mencapai 54.540.300 jiwa, sedangkan yang berumur 25-64 tahun berjumlah 38.959.165 jiwa dan yang berumur $>65$ tahun berjumlah 7.968 .876 jiwa. Melihat jumlahnya yang sangat besar, maka remaja sebagai generasi penerus bangsa perlu dipersiapkan menjadi manusia yang sehat secara jasmani, rohani dan mental spritual (Bakti, 2010 dalam Pandiangan, 2005).

Di Indonesia, wanita yang mengalami keputihan ini sangat besar, $75 \%$ wanita Indonesia kemungkinan mengalami keputihan minimal satu kali dalam hidupnya. Lebih dari $70 \%$ wanita Indonesia mengalami keputihan yang disebabkan oleh jamur dan parasit seperti cacing kremi atau kuman (Trikomonas Vaginalis). Angka ini berbeda tajam dengan Eropa yang hanya $25 \%$ saja. Kondisi cuaca Indonesia yang lembab menjadi salah satu penyebab banyaknya wanita Indonesia mengalami keputihan, kondisi ini berbeda dengan Eropa yang hawanya kering sehingga wanita tidak mudah terinfeksi jamur (Noviati, 2008 dalam Elistyawaty, 2006).

Perawatan di seputar organ intim kewanitaan jika tidak diperhatikan maka dapat menimbulkan berbagai penyakit. Penyakit-penyakit yang sering dikeluhkan banyak wanita adalah keputihan, kekuningan, bau tak sedap pada organ intim kewanitaan, merasa gerah dan gatal, infeksi vagina yang disebabkan oleh bakteri hingga infeksi kandung kemih yang disebabkan bakteri. Data dari poliklinik Penyakit Menular Seksual (PMS) RSUD Moewardi Solo, pada tahun 2007 kejadian PMS menempati urutan ketiga, dimana penderitanya sebagian besar usia produktif. Sedangkan urutan pertama adalah penyakit keputihan akibat jamur dan penyakit keputihan akibat bakteri menempati urutan kedua.

Seorang Ahli Fakultas Kesehatan Indonesia menyebutkan bahwa 99,7\% kanker serviks disebabkan oleh Human Papiloma Virus (HPV). Kanker serviks merupakan kanker urutan kedua setelah kanker payudara yang menyerang wanita di dunia dan urutan pertama di negara berkembang. Yayasan Kanker Indonesia memperkirakan terjadi 41 kasus baru kanker serviks dan 20 perempuan meninggal dunia setiap harinya (Astana, 2009).

\section{METODE}

Jenis penelitian kuantitatif dengan desain Cross Sectional. Data primer dikumpulkan melalui kuisioner, baik variabel independen (pengetahuan dan sikap) maupun variabel dependen (perawatan organ reproduksi wanita).

Untuk variabel pengetahuan, skala yang digunakan adalah skala Guttman. Interpretasi penilaian dilakukan dengan 3 kategori hasil ukur yaitu baik jika skor jawaban $>76 \%$ ( $>23$ ), cukup jika skor jawaban $56-76 \%(18-22)$ dan kurang jika skor jawaban $<56 \%$ $(<17)$ (Nursalam, 2003).

Variabel sikap skala yang digunakan dalam penelitian ini adalah skala Likert, dengan kategori sangat setuju, setuju, tidak setuju, sangat tidak setuju. Interpretasi penilaian akan dilakukan dengan hasil ukur positif $\geq$ mean $(40,68)$ dan negatif $<$ mean $(40,67)$ (Hidayat, 2007). 


\section{HASIL}

\section{Analisis Univariat}

Hasil penelitian menunjukan bahwa hanya sebagian kecil saja, mahasiswi yang berpengetahuan cukup (14,0\%); kurang dari separuh mahasiswi bersikap negatif $(41,0 \%)$ dan hanya $48 \%$ mahasiwi yang tidak melakukan perawatan (Tabel 1).

\section{Analisis Bivariat}

Hasil penelitian didapatkan bahwa responden yang berpengetahuan baik yang melakukan tindakan perawatan organ reproduksi wanita dengan baik sebesar 58,1\%, $p=0,006$ yang berarti ada hubungan yang signifikan antara pengetahuan dengan tindakan perawatan organ reproduksi wanita yaitu dengan nilai OR 8,33 $(95 \%$ CI:1,75-39,45) artinya responden yang berpengetahuan baik mempunyai peluang untuk melakukan tindakan perawatan organ reproduksi 8,33 kali dibandingkan responden yang berpengetahuan cukup. Kemudian $64,4 \%$ responden yang mempunyai sikap positif melakukan tindakan perawatan organ reproduksi, $p=0,006$ berarti ada hubungan yang signifikan antara sikap dengan tindakan perawatan organ reproduksi wanita dengan nilai OR 3,49 $(95 \%$ CI:1,51-8,06) artinya responden yang memiliki sikap positif mempunyai peluang untuk melakukan tindakan perawatan organ reproduksi wanita 3,49 kali dibandingkan responden yang bersikap negatif (Tabel 2).

Tabel 1

Distribusi Frekuensi Pengetahuan, Sikap dan Tindakan pada Mahasiswi di Akademi Kebidanan Internasional Pekanbaru Tahun 2011

\begin{tabular}{llcc}
\hline Variabel & Kategori & Frekuensi & Persentase \\
\hline \multirow{2}{*}{ Pengetahuan } & Baik & 86 & 86,0 \\
& Cukup & 14 & 14,0 \\
\multirow{2}{*}{ Sikap } & Positif & 59 & 59,0 \\
\multirow{2}{*}{ Tindakan } & Negatif & 42 & 41,0 \\
& Ya & 52 & 52,0 \\
& tidak & 48 & 48,0 \\
\hline
\end{tabular}

Tabel 2.

Hubungan Pengetahuan dan Sikap dengan Tindakan Perawatan Organ Reproduksi pada Mahasiswi di Akademi Kebidanan Internasional Pekanbaru Tahun 2011

\begin{tabular}{|c|c|c|c|c|c|c|}
\hline \multirow{2}{*}{ Variabel } & \multirow{2}{*}{ Kategori } & \multicolumn{2}{|c|}{ Tindakan } & \multirow{2}{*}{ Total } & \multirow{2}{*}{$\begin{array}{c}p \\
\text { value }\end{array}$} & \multirow{2}{*}{ OR $(95 \% C I)$} \\
\hline & & Ya & Tidak & & & \\
\hline \multirow[t]{2}{*}{ Pengetahuan } & Baik & $50(58,1 \%)$ & $36(41,9 \%)$ & $86(100 \%)$ & \multirow{2}{*}{0,006} & 8,33 \\
\hline & Cukup & $2(14,3 \%)$ & $12(85,7 \%)$ & $14(100 \%)$ & & $(1,75-39,54)$ \\
\hline \multirow[t]{2}{*}{ Sikap } & Positif & $38(64,4 \%)$ & $21(35,6 \%)$ & $59(100 \%)$ & \multirow{2}{*}{0,006} & 3,49 \\
\hline & Negatif & $14(34,1 \%)$ & $27(65,9 \%)$ & $41(100 \%)$ & & $(1,51-8,06)$ \\
\hline
\end{tabular}

\section{PEMBAHASAN}

Berdasarkan hasil penelitian didapatkan bahwa responden berpengetahuan baik dalam melakukan tindakan perawatan organ reproduksi dengan persentase sebesar $58,1 \%$ dengan $p=0,006$ nilai OR $8,33(95 \%$ CI : $1,75-39,45)$ bahwa ada hubungan yang signifikan antara pengetahuan dengan tindakan perawatan organ reproduksi wanita berarti sebagian besar responden sudah terpapar dengan bahan bacaan, baik itu yang berupa media cetak maupun media elektronik, teman sebaya dan orang tua yang terkait dengan perawatan organ intim pada wanita.

Hasil penelitian ini juga sesuai dengan teori yang dikemukakan oleh Green (1980) dalam Notoatmodjo (2003) bahwa pengetahuan merupakan domain yang sangat penting untuk terbentuknya perilaku seseorang. Apabila suatu perilaku didasari oleh pengetahuan, maka perilaku tersebut akan berlangsung lama sebaliknya jika perilaku tersebut tidak didasari pengetahuan dan kesadaran maka perilaku tersebut tidak akan berlangsung lama. Perilaku yang didasari oleh pengetahuan akan lebih langgeng dari pada perilaku yang tidak didasari oleh pengetahuan. Selain itu, pengetahuan merupakan faktor predisposisi yang mempengaruhi perilaku seseorang.
Jika ditinjau dari segi umur, responden berada pada usia remaja akhir (17 tahun hingga 20 tahun). Pada usia tersebut remaja lebih berkonsentrasi pada rencana yang akan datang, meningkatkan pergaulan, proses berpikir secara kompleks digunakan untuk memfokuskan diri pada masalah-masalah idealisme, toleransi, keputusan untuk karier dan pekerjaan, serta peran orang dewasa dalam masyarakat (Soetjiningsih , 2007 dalam Aryani, 2010). Hal ini dapat diartikan bahwa responden mengetahui bahwa tindakan perawatan organ reproduksi wanita sangat penting untuk dipraktikan dan memiliki manfaat yang baik bagi kesehatan reproduksi wanita.

Asumsi peneliti terhadap penelitian ini adalah bahwa pengetahuan responden yang baik merupakan suatu yang ideal. Hal ini dipengaruhi oleh pendidikan dan pengalaman yang dialami responden itu sendiri. Semakin baik pengetahuan responden maka semakin tahu cara tindakan perawatan organ reproduksi. Dapat disimpulkan bahwa, pengetahuan yang baik yang dimiliki oleh responden akan mempengaruhi cara tindakan perawatan organ reproduksi wanita. Salah satu upaya yang dilakukan responden terhadap tindakan perawatan organ reproduksi yaitu dengan membersihkan alat kelamin dari arah depan ke bela- 
kang menggunakan air bersih dan mengalir maka perilaku responden sudah berubah menjadi lebih baik.

Selain pengetahuan responden, tindakan perawatan organ reproduksi juga dipengaruhi oleh sikap. Berdasarkan hasil penelitian didapatkan bahwa responden bersikap positif terhadap tindakan perawatan organ reproduksi sebesar $64,6 \%$ dengan $\mathrm{p}=$ 0,006. Terdapat hubungan sikap dengan tindakan perawatan organ reproduksi wanita dengan nilai OR 3,49 (95\% CI : 1,51-8,06). Sikap positif yang dimiliki responden dikarenakan oleh pengetahuan yang baik yang dimiliki oleh responden.

Hasil penelitian ini didukung oleh teori Notoatmodjo (2003) bahwa salah satu hasil atau dampak positif dari proses belajar adalah terjadinya perubahan ranah sikap yaitu kesadaran dan adanya peningkatan sikap yang positif terhadap apa yang diterima. Dalam penelitian ini, responden yang bersikap positif dipengaruhi oleh pengetahuan yang baik. Selain itu, sikap adalah sesuatu faktor predisposisi yang mempengaruhi perilaku individu.

Menurut Robbins (2003) sikap juga dapat dipengaruhi oleh situasi atau lingkungan sekitar, karakteristik pribadi dari individu tersebut. Hal ini berarti apabila di lingkungan sekitar responden melakukan tindakan perawatan organ reproduksi wanita maka responden juga akan ikut melakukan cara perawatan yang benar. Menurut Green (1980) dalam Notoatmodjo (2003), sikap merupakan suatu kecenderungan untuk mengadakan tindakan terhadap suatu stimulasi, sikap sering diperoleh dari pengalaman, baik pengalaman sendiri maupun pengalaman orang lain.

Jika ditinjau dari segi psikologi ada 4 faktor yang mempengaruhi sikap antara lain pertama yaitu kebutuhan. Ketika seseorang membutuhkan sesuatu atau memiliki ketertarikan akan suatu hal atau menginginkannya, maka yang bersangkutan akan dengan mudah mempersepsikan sesuatu berdasarkan kebutuhan tersebut. Kedua yaitu kepercayaan, berupa sesuatu yang dianggap benar yang dapat mempengaruhi interprestasi seseorang terhadap sinyal sensorik yang ambigu. Ketiga yaitu emosi, dapat mempengaruhi interpretasi seseorang mengenai suatu informasi sensorik. Keempat yaitu ekspektasi, yaitu pengalaman masa lalu sering mempengaruhi sikap seseorang (Wade dan Travis, 2007). Jika dibandingkan dengan hasil penelitian ini berarti sikap positif yang dimiliki responden untuk melakukan perawatan organ reproduksi wanita dikarenakan responden membutuhkannya dan memiliki kepercayaan untuk melakukannya dengan baik serta pengalaman dimasa lalu yang ada pengaruhnya apabila mahasiswi tersebut melakukannya sehari-hari.

Mann dalam Azwar (2003) juga menjelaskan bahwa sikap itu terutama aspek emosional yang biasanya berakar paling dalam sebagai komponen sikap. Hal ini menyebabkan aspek ini paling bertahan terhadap pengaruh yang mungkin akan mengubah sikap seseorang.

\section{KESIMPULAN}

Berdasarkan hasil penelitian dapat diambil kesimpulan sebagai berikut:

1. Responden yang mempunyai pengetahuan baik $86 \%$, sikap positif sebanyak 59\% dan melakukan tindakan perawatan organ reproduksi wanita $52 \%$.

2. Adanya hubungan yang signifikan antara pengetahuan dengan tindakan perawatan organ reproduksi wanita. Hasil uji chi square $p<0,05$ (0.006) dengan OR 8,33 (95\% CI : 1,75-39,54).

3. Adanya hubungan yang signifikan antara sikap dengan tindakan perawatan organ reproduksi wanita. Hasil uji chi square $p<0,05(0,006)$ dengan OR 3,49 (95\% CI : 1,51-8,06).

4. Secara umum dapat disimpulkan bahwa responden memiliki pengetahuan yang baik dan bersikap positif melakukan tindakan perawatan organ reproduksi dengan baik dan benar.

\section{SARAN}

Diharapkan bagi tempat penelitian agar memasukkan materi tentang perawatan organ reproduksi wanita yang baik dan benar pada mata kuliah yang terkait, seperti mata kuliah kesehatan reproduksi. Untuk penelitian selanjutnya dilakukan pada remaja awal dikarenakan perawatan organ reproduksi wanita yang sangat penting bagi setiap wanita dan dengan jenis penelitian yang berbeda serta menambah variabel penelitian.

\section{DAFTAR PUSTAKA}

Adolof, Ronny. (2009). Jumlah Penduduk Dunia 2009. http://id.wikipedia.org/wiki/daftar negara menurut jumlah penduduk. Diakses 11 April 2011.

Astana, M. (2009). Bersahabat dengan Kanker. Yogyakarta: Araska

Azwar. (2003). Sikap manusia, Teori dan Pengukurannya. Yogyakarta : Pustaka Pelajar.

Aryani, Ratna, dkk. 2010. Kesehatan Remaja Problem dan Solusinya. Jakarta : Salemba Medika.

Bakti, Martinda. (2010). Hubungan antara Tingkat Pengetahuan Kesehatan Reproduksi dengan Perilaku Seksual Remaja Siswa-Siswi SMAN 1 Sukoharjo. Skripsi. Tidak diterbitkan. Universitas Sebelas Maret Surakarta.

Dwikarya, Maria. (2004). Menjaga Organ Intim. Jakarta : Kawan Pustaka 
Ganie, M. (2009). Gambaran Pengetahuan, Sikap da Tindakan tentang 3M (Mengubur Barang Bekas, Menutup dan Menguras Tempat Penampungan Air) pada Keluarga di Kelurahan Padang Bulan. Skripsi. Tidak diterbitkan.

Hidayat, A. Azis Alimul. (2009). Metode Penelitian Kebidanan Teknik Analisis Data. Jakarta : Salemba Medika.

Keraf, Sonny. \& Mikhael. (2007). Ilmu Pengetahuan sebuah Tinjauan Filosofi. Kanisius : Jakarta.

Maulana, Mirza. 2008. Memahami Kesehatan Reproduksi, Cara Menghadapi Kehamilan dan Kiat Mengasuh Anak. Yogyakarta : Katahati.

Notoatmodjo, S. (2003). Pendidikan dan Perilaku Kesehatan. Jakarta: Rineka Cipta.

Notoatmodjo, S. (2005). Metodologi Penelitian Kesehatan. Jakarta : Rineka Cipta.

Notoatmodjo, S. (2007). Promosi Kesehatan dan Ilmu Perilaku. Jakarta : Rineka Cipta.

Noviati, Wiwit Putri. (2008). Hubungan antara tingkat pengetahuan dan perilaku merawat organ genetalia eksterna wanita dengan keputihan yang dialami siswi SMA Negeri 2 Semarang. Skripsi. Tidak diterbitkan.

Nursalam. (2003). Konsep dan Penerapan Metodologi Penelitian Ilmu Keperawatan. Jakarta : Salemba Medika.

Purwanti, Eni Retno. (2009). Hubungan pengetahuan tentang kesehatan reporoduksi remaja dengan praktik perawatan organ reproduksi eksternal pada siswi SMA N 2 Mranggen Kabupaten Demak. Skripsi. Tidak diterbitkan.
Riduwan. (2009). Skala Pengukuran Variabel-variabel Penelitian. Bandung : Alfabeta.

Robbins. (2003). Perilaku Organisasi Jilid I. Jakarta : PT. Indeks Kelompok Gramedia

Salim, Carolina. (2009). Cara Merawat Alat Kelamin. http://www.artikel/2009/01/cara-merawat-alatkelamin 16 Januari 2009. Diakses 11 April 2011.

Sarwono, Sarlito Wirawan. (2008). Psikologi Remaja. Edisi Revisi. Jakarta : PT Raja Gravindo Persada.

Siswono. (2001). “Clinical Governance” untuk Cegah Kesalahan Medik. in, Indonesian Nutrition Network, $28 \quad$ November 2001. http://creasoft.wordpress.com/2009/04/16/pera watan-organ-reproduksi-eksternal-wanita/. Diakses 10 Maret 2011

Sobur, Alex. (2003). Psikologi Umum. Bandung : Pustaka Setia

Sloane, E. (2003). Anatomi dan Fisiologi Untuk Pemula. Jakarta : EGC

Soetjiningsih. (2007). Tumbuh Kembang Remaja dan Permasalahannya. Jakarta: Sagung Seto

Wade. C dan Travis. C. (2007). Psikologi edisi ke 9 Jilid I dan II. Jakarta : Erlangga

Wiknjosastro, H. (2005). Ilmu Kebidanan. Jakarta : YBPS 